\title{
Analysis of a Collection of Early Caddo Artifacts from the Davis- McPeek Mound Site (41UR4/99), Upshur County, Texas
}

Timothy K. Perttula

Heritage Research Center, Stephen F. Austin State University

Follow this and additional works at: https://scholarworks.sfasu.edu/ita

Part of the American Material Culture Commons, Archaeological Anthropology Commons, Environmental Studies Commons, Other American Studies Commons, Other Arts and Humanities Commons, Other History of Art, Architecture, and Archaeology Commons, and the United States History Commons

Tell us how this article helped you.

This Article is brought to you for free and open access by the Center for Regional Heritage Research at SFA ScholarWorks. It has been accepted for inclusion in Index of Texas Archaeology: Open Access Gray Literature from the Lone Star State by an authorized editor of SFA ScholarWorks. For more information, please contact cdsscholarworks@sfasu.edu. 


\section{Analysis of a Collection of Early Caddo Artifacts from the Davis-McPeek Mound}

Site (41UR4/99), Upshur County, Texas

\section{Creative Commons License}

\section{(c) (1) (8)}

This work is licensed under a Creative Commons Attribution-NonCommercial 4.0 International License 


\title{
Analysis of a Collection of Early Caddo Artifacts from the Davis-McPeek Mound Site (41UR4/99), Upshur County, Texas
}

\author{
Timothy K. Perttula
}

\section{INTRODUCTION}

The Davis-McPeek site (41UR4/99) is an Early Caddo (ca. A.D. 900-1200) mound and associated village on an alluvial terrace along Little Cypress Creek, in western Upshur County in East Texas (Figure 1). The site, with one known mound, has been known since the early 1930s, and in the early 1960s Buddy Jones conducted archaeological investigations in the mound (Davis et al. 1971). A small collection of ancestral Caddo artifacts from that work are curated at the Gregg County Historical Museum (GCHM, Longview, Texas), and this article provides an analysis of this collection.

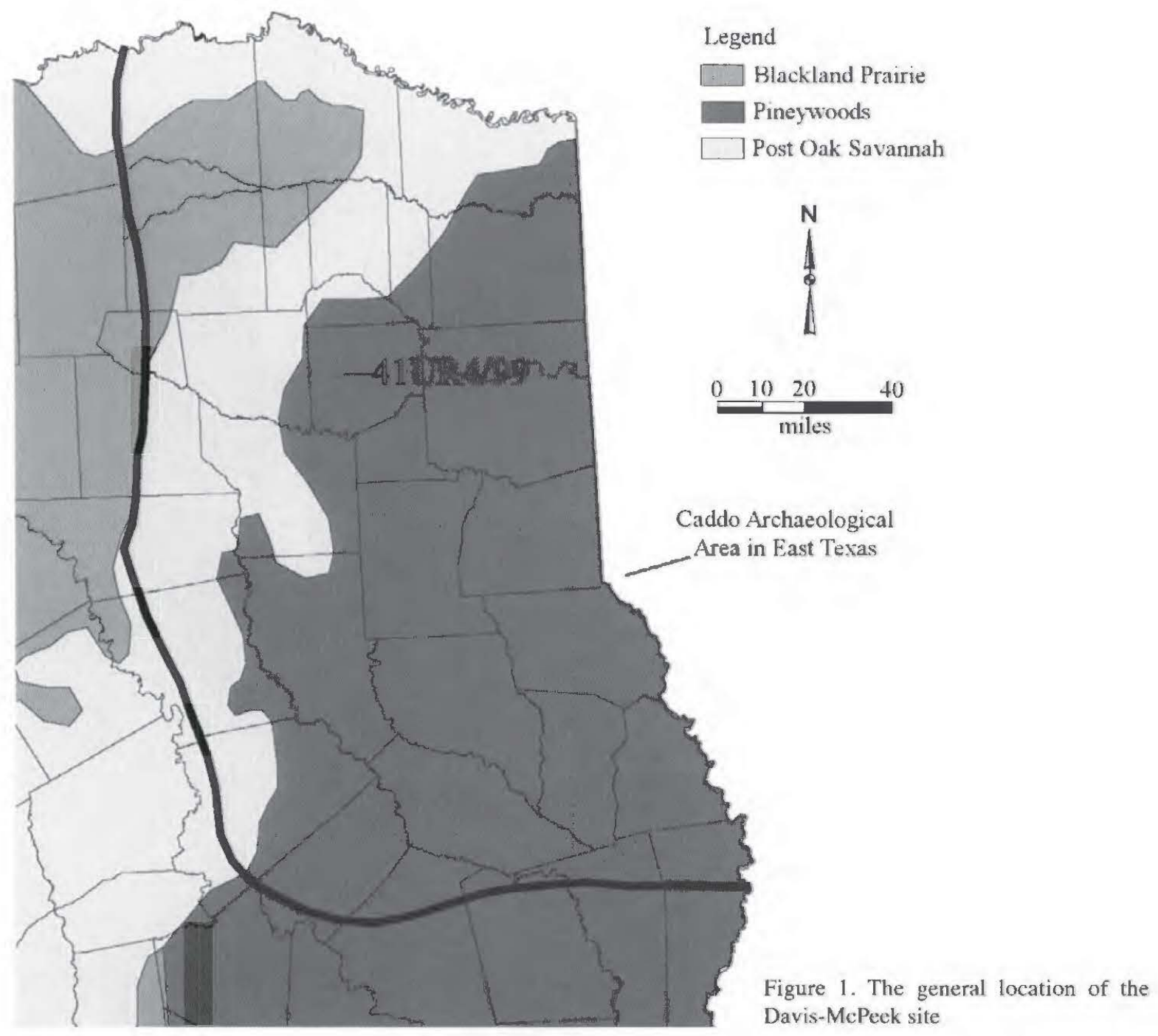




\section{AVAILABLE INFORMATION ABOUT THE DAVIS-MCPEEK SITE}

A. T. Jackson of The University of Texas at Austin first recorded the Davis-McPeek site in 1931, although a Mr. H. M. Prince had dug a burial with pottery vessels at the site sometime before 1930. In 1939, A. M. Woolsey of the federal Works Progress Administration-University of Texas Project investigations in East Texas re-recorded the site and obtained a small surface collection of ceramic sherds $(n=35)$. Woolsey noted that the mound stood $4.6 \mathrm{~m}$ in height and was $15.2 \times 9.2 \mathrm{~m}$ in length and width, and that the mound was constructed of sand (Nelson and Perttula 1993:53).

At the $7^{\text {th }}$ Caddo Conference in 1963, Buddy Calvin Jones reported on his investigations at the site, which he called the Spencer Davis Mound. The mound was divided by a north-south property line fence, with the eastern half of the mound owned by J. Davis and the western half owned by E. L. Spencer (Figure 2). Notes on file at the GGHM indicate that Jones excavated about half of the western side of the mound (on the Spencer property) (Figure 2). He also excavated onc Caddo burial that was under the mound fill. The burial was oriented roughly east-west, and there were two pottery vessels at the western end of the burial pit, probably by the feet of the deceased individual. The vessels were of the Crockett Curvilinear Incised and Holly Fine Engraved types (Davis et al. 1971:103); the vessels have not yet been identified in the GCHM vessel collections. Jones also indicated that vessels of the types Dunkin Incised, Crockett Curvilinear Incised, and Weches Fingernail Impressed had been removed from the mound by other individuals (Davis et al. 1971:103).

Jones' notes on his mound excavations indicate that the mound stood approximately $2.4 \mathrm{~m}$ in height in the early $1960 \mathrm{~s}$. The profile in his excavation area showed a $30-35 \mathrm{~cm}$ thick Ahorizon atop the mound, followed by several mound fills, namely: a $25-40$ $\mathrm{cm}$ zone of a yellowish-red clay; $25-30$ $\mathrm{cm}$ of a white sand; $50 \mathrm{~cm}$ of a yellowish sand; and a basal fill (ca. $85 \mathrm{~cm}$ thick) of a yellowish sand with gray, yellow, white, orange, and dark yellow clay lens, charcoal fragments, and a few sherds. The sherds to be discussed below came from this basal mound deposit, and were likely incorporated in sediments (from nearby habitation deposits) gathered up on the site with which to construct the mound.

Following Jones' work, Bob D. Skiles of the Wood County Archaeological Survey relocated the mound in 1979, along with an associated midden deposit (earlier noted by Woolsey, see Nelson and Perttula 1993:Figure 1). He made a surface collection from the midden, and this included an Alba point, a Red River long-stemmed pipe sherd, and eight

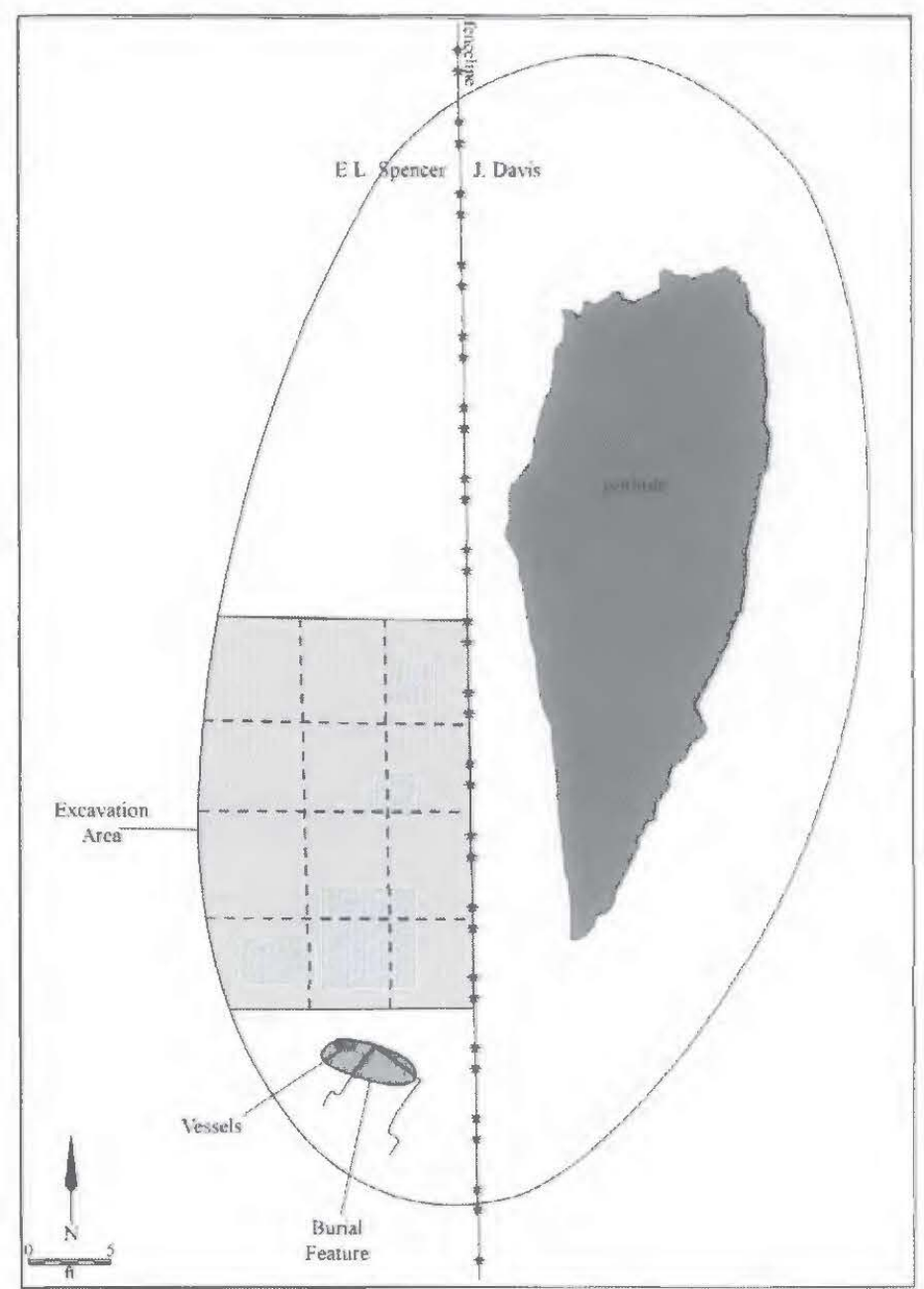

Figure 2. Buddy Jones' excavations in the mound at the Davis-McPeek site. 
ceramic sherds. These included a Coles Creek Incised rim, and a Spiro Engraved bowl sherd, as well as other incised and punctated body sherds and an incised jar handle.

Finally, in 1993, Nelson and Perttula (1993), along with Mike Turner, investigated the site, now named the Davis-McPeek mound after the current landowners. Thirteen shovel tests were excavated on two alluvial terrace knolls north of the mound itself (Nelson and Perttula 1993:Figure 2). These shovel tests encountered two probable house areas on the knolls with concentrations of sherds, lithic debris, and daub in a ca. $50 \mathrm{~cm}$ thick archaeological deposit. The southern concentration, about 15 m northeast of the mound, had a notable daub concentration covering ca. $50 \mathrm{~m}^{2}$ area, likely marking the location of an Early Caddo house.

The 1993 shovel testing and an associated surface collection recovered 728 prehistoric artifacts from the site, including daub $(n=488)$, plain and decorated sherds $(n=76$, with a plain to decorated sherd ratio of 5.33), lithic debris $(n=107)$, chipped stone tools $(n=3$, including an Alba arrow point), animal bones $(n=32)$, and charcoal and charred nutshells $(n=22)$. The few decorated sherds are incised and punctated, including diagonal and horizontal incised rims and fingernail and tool-impressed punctations. Two of the sherds are from the rim of plain bowls with inverted rim profiles.

\section{ARTIFACT COLLECTION}

There is a small collection of Caddo ceramic sherds and lithic artifacts in the Buddy Jones collection from the Davis-McPeek site. Although they have no specific provenience, they came from excavations Buddy Jones completed in the western half of the mound at the site in the early $1960 \mathrm{~s}$, near a burial he uncovered at the base of the mound.

There are 40 ceramic sherds in the Jones collection from the site. The sherds include six decorated body sherds (none of them brushed, lending credence to the likelihood that the ceramic assemblage predates ca. A.D. 1250), five plain rim sherds, 25 plain body sherds, and four base sherds. The plain to decorated sherd ratio is a high 5.67; however, this is not significantly different from the plain to decorated sherd ratio in the 1993 assemblage reported by Nelson and Perttula (1993). More than $92 \%$ of the sherds are grog-tempered, $5 \%$ are grog-bone-tempered, and $2.5 \%$ are bone-tempered. Four of the plain rim sherds are from bottles, while the other is from a carinated bowl with a direct profile and a rounded lip.

The six decorated sherds are from Early Caddo fine wares and utility wares. The fine wares include a bottle sherd from a Holly Fine Engraved bottle with fine line concentric semi-circles, and another bottle sherd with a straight engraved line. Two of the utility ware sherds have straight or closely-spaced parallel incised lines. One body sherd is identified as banded punctated, a variety of utility ware commonly found on Early Caddo sites in northwest Louisiana and East Texas (see Girard 2012; Perttula 2011) with small triangular punctates on either side of a straight incised line. The last decorated sherd is from a Weches Fingernail Impressed, var. Weches (see Stokes and Woodring 1981:Figures 22n-q and 23a) jar. It has horizontal and vertical incised lines above a row of crescent-shaped punctations.

The lithic artifacts from the excavations include only a single cortical piece of petrified wood lithic debris and a quartzite fire-cracked rock.

\section{SUMMARY AND CONCLUSIONS}

The small collection of ceramic and lithic artifacts from the Davis-McPeek site in the Buddy Jones collection at the GCHM provides further evidence of the character of the Early Caddo ceramic assemblage at the site, and the fact that mound construction and domestic occupation were contemporaneous here. Jones' excavations revealed that the mound at the site was built from both sand and clay fills, sometimes intermixed, and ceramic sherds and charcoal fragments were present in the lowermost mound fill deposits. Jones also excavated a single sub-mound burial feature at the Davis-McPeek site, and this individual was accompanied 
by two pottery vessels. The vessels and the sherds in various collections from the site are consistent with a ca. A.D. 900-1200 Caddo occupation in East Texas, with types identified including Holly Fine Engraved, Spiro Engraved, Crockett Curvilinear Incised, Coles Crcek Incised, Dunkin Incised, and Weches Fingernail Impressed. Alba arrow points and a Red River long-stemmed pipe sherd are also part of the Early Caddo material culture assemblage at the Davis-McPeek mound site and village.

\section{ACKNOWLEDGMENTS}

I appreciate the assistancc of Patti Haskins, Curator at the Gregg County Historical Museum, in facilitating the study of the artifact collection from the Davis-McPeek site in the Buddy Jones collection. Lance Trask prepared the figures for the article.

\section{REFERENCES CITED}

Davis, H. A., D. G. Wyckoff, and M. A. Holmes (editors)

1971 Proceedings of the Seventh Caddo Conference. Occasional Publication No. 1. Oklahoma Archeological Survey, Norman.

Girard, J. S.

2012 Recent Investigations at the Mounds Plantation Site (16CD12), Caddo Parish, Louisiana. Caddo Archeology Journal 22:21-62.

Nelson, B. and T. K. Perttula

1993 The Z. V. Davis-McPeek Site, an Early Caddoan Mound Site in the Little Cypress Creek Valley, Upshur County, Texas. Notes on Northeast Texas Archaeology 2:50-65.

Perttula, T. K. (assembler)

2011 (assembler) Archaeological and Archaeogeophysical Investigations at an Early Caddo Mound Center in the Sabine River Basin of East Texas, Special Publication No. 15. Friends of Northeast Texas Archacology, Austin and Pittsburg.

Stokes, J. and J. Woodring

1981 Native-Made Artifacts of Clay. In Archeological Investigations at the George C. Davis Site, Cherokee County, Texas: Summers of 1979 and 1980, edited by D. A. Story, pp. 135-238. Occasional Paper No. 1. Texas Archeological Research Laboratory. The University of Texas at Austin. 